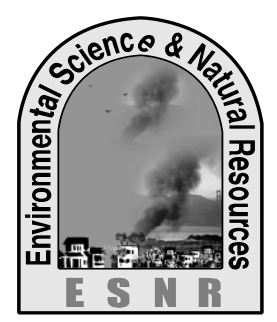

\title{
Application of Inorganic Fertilizers and Organic Manures on the Production of Autotrophic Plankton in Madhupur Tract Soil Contained Miniature Tank
}

\author{
M. E. Huda ${ }^{1 *}$ and M. R. Nabi ${ }^{2}$ \\ ${ }^{1}$ Department of Environmental Sciences, Jahangirnagar University, Savar-Dhaka, \\ ${ }^{2}$ Department of Zoology, Jahangirnagar University, Savar-Dhaka. \\ *Corresponding author: mdemadul@yahoo.com
}

\begin{abstract}
Appropriate fertilizer and their impact on physico-chemical parameters of water and productivity is very important for aquaculture and ecology. Optimum fertilizer dose can help in fish farmer as well as aquaculture sector. From the study it was found that the total physicochemical parameters of water were suitable for aquaculture, drinking water, irrigation and domestic use. The average water temperature was $26.45 \pm 2.75^{\circ} \mathrm{C} ; 26.50 \pm 3.24^{\circ} \mathrm{C} ; 25.83 \pm 4.08^{\circ} \mathrm{C} ; 26.57 \pm 3.02^{\circ} \mathrm{C}$ and $26.53 \pm 2.93^{\circ} \mathrm{C}$ for MCRT-1 to 5 gradually. Water $\mathrm{p}^{\mathrm{H}}$ in an average was $7.37 \pm 0.61 ; 7.44 \pm 0.55 ; 7.25 \pm 0.58 ; 7.33 \pm 0.54$ and $7.47 \pm 0.49$ for Minature Circular Research Tank (MCRT)-1 to 5 respectively. Average water DO were $6.98 \pm 1.05 \mathrm{mgl}^{-1} ; 6.75 \pm 1.53 \mathrm{mgl}^{-1} ; 6.90 \pm 1.64 \mathrm{mgl}^{-1} ; 6.59 \pm 1.19 \mathrm{mgl}^{-1}$ and $6.77 \pm 1.60 \mathrm{mgl}^{-1}$ for MCRT-1 to 5 respectively. Average water hardness were $71.88 \pm 20.47 \mathrm{mgl}^{-1} ; 60.5 \pm 21.25 \mathrm{mgl}^{-1} ; 83.38 \pm 23.39 \mathrm{mgl}^{-1} ; 59.13 \pm 25.57$ $\mathrm{mgl}^{-1}$ and $52.63 \pm 7.92 \mathrm{mgl}^{-1}$ for MCRT-1 to 5 gradually. Average water total phosphorus were $0.77 \pm 0.18 \mathrm{mgl}^{-1} ; 0.83 \pm 0.19 \mathrm{mgl}^{-1}$; $0.78 \pm 0.21 \mathrm{mgl}^{-1} ; 0.84 \pm 0.17 \mathrm{mgl}^{-1}$ and $0.84 \pm 0.16 \mathrm{mgl}^{-1}$ for MCRT-1 to 5 gradually. From planktonic study it was found that the highest phytoplankton and Zooplankton were in MCRT-3. Phytoplanktons were under 27 no. of genera. Their groups were Cyanophyceae, Chlorophyceae, Bacillariophyceae, Euglenophyceae and Hepatecae.Zooplankton were five major taxa and they were Protozoa, Rotifera, Cladocera, Copepod and Ostracoda respectively.
\end{abstract}

Key words: Ecology, Fertilizer, Miniature tank and Productivity

\section{Introduction}

Fertilization of pond with inorganic and organic sources is now an indispensable part (Bhakta, 2006) for all kinds of aquaculture particularly fish through stimulating the autotrophic pathway (De Silva and Hasan, 2007; Jha, 2008).In this practice, the inorganic fertilizer has been more accepted because of its lower loading rates, higher nutrient content and lower oxygen demand (Colman and Edwards, 1987) as such, increasingly used in carp culture ponds throughout the Asian countries from the seventies of last century. Here, the bottom soil acts like a reservoir to supplement the upper laying water column with the required nutrient is necessity. The soluble inorganic fertilizers make their elements available to the water immediately these are applied, while, the organic manures comparatively slower rate of release of nutrients to the water over a long period of time as the decomposition proceeds. Besides, the organic manures enrich the organic matter content of soil and water and, within the limits of manurial dose, release carbon dioxide and nutrients on decomposition, sustaining the fertility of water, unless hasten the depletion of dissolved oxygen and enhance production of toxic gases (Huet, 1975; Jhingran, 1985; Pillay, 1993). Application of different types and proportions of organic manures may also differ according to soil types. Several pioneer workers, such as, Zehmen (1917), Schaperclaus (1933), Le Mare (1948), Alikunhi (1955), Hora and Pillay (1962), Huet (1975), Jhingran (1985); Pillay, (1993); Lickacz and Penny, (2001) have reviewed the application of farmyard manures in different water bodies in their respective areas. Bangladesh, because of its geographical location supports huge number of lentic and lotic water bodies. It is encouraging that these water bodies are now getting more and more importance to the owners either by themselves or leasing management practices in fish production to mitigate animal protein deficiency for the burgeoning population of the country (Mazid, 2002). Whereas, in total production of fish from a water body, fertilization and artificial feeding are considered as a major cost enhancing sector due to either under or over supply and thus needs standardization through time to time scientific studies. Physico-chemical parameter of water is very important factor for aquaculture. This parameters determine the planktonic condition of a water body. The present study is an initiative to settle the possible fertilizer dose in case of the Madhupur tract soil type of Bangladesh through trials in a miniature earthen tank. This study will help the fish farmer in their fertilizer use in pond fish culture.

\section{Materials and Methods}

\section{Research tanks}

Five miniature circular research tanks (MCRTs), each of $0.88 \mathrm{~m}^{2}$ in diameter were used for this research work. For the obtaining scientific data in every step of research, these were established in usually sunny and well aerated place adjacent to the Environment Sciences Department, JU. Initially, one-third of each MCRT was covered with the Madhupur tract soil collected from the respective area and mixed with the following doses of organic manures but, always with $263 \mathrm{Kgha}^{-1}$ lime (excluding MCRT-5) two days before filled up with natural pond water up to its neck.

\section{Preparation of MCRTs}

For recording, all the MCRTs were numbered 1-5 respectively and accordingly MCRT-5 was used as a controlled tank with neither of the treatments. After two days of watering, following doses of inorganic fertilizers were applied against the production of autotrophic plankton in different MCRTs. 
To follow the standard unit, applied treatments were expressed in $\mathrm{Kgha}^{-1}$.

Organic manures and Inorganic fertilizers

Tanks Poultry drops (dry) Urea

$4375 \mathrm{kgha}^{-1} \quad 137 \mathrm{kgha}^{-1} \quad 117 \mathrm{Kgha}^{-1}$

MCRT-1 $4375 \mathrm{kgha}^{-1} \quad 137 \mathrm{kgha}^{-1} \quad 117 \mathrm{Kgha}^{-1}$

MCRT-2 $2923 \mathrm{kgha}^{-1} \quad 29.2 \mathrm{kgha}^{-1} \quad 525 \mathrm{Kgha}^{-1}$

MCRT-3 $1736 \mathrm{kgha}^{-1} \quad 188 \mathrm{kgha}^{-1} \quad 425 \mathrm{Kgha}^{-1}$

MCRT-4 $2500 \mathrm{kgha}^{-1} \quad 106 \mathrm{kgha}^{-1} 224 \mathrm{Kgha}^{-1}$

MCRT-5 Controlled.

\section{Sampling}

For water quality analysis, samples of water were collected 15 days after the preparation of MCRTs and the process continued accordingly March to February, 2012. For this reason, water samples were collected from each MCRT separately with a $250 \mathrm{ml}$ beaker within 4:00 - 5:00 pm and instantly water temperature was determined using a Celsius thermometer (scale ranging from $0-100^{\circ} \mathrm{C}$; Model: $\mathrm{SH}-135 \mathrm{CE}$, China). Then, water $\mathrm{pH}$, Dissolved oxygen, Total hardness and Total phosphorus were analyzed using standard methods as suggested by AOAC (1989) and APHA (1998). For the qualitative and quantitative study of autotrophic plankton, $100 \mathrm{ml}$ water samples were collected before the water parameters analyses from each MCRT and immediately preserved in a conical flask containing Lugol's solution and counted in the laboratory under a Nikon compound microscope (Japan) at a magnification of 400x and the procedure repeated three times with each sample.

Calculation:

Density as individualL $L^{-1}=\left(\mathrm{V}_{1} \times \mathrm{V}_{2}\right) \times \mathrm{T} \times 1000$

where, $\mathrm{V}_{1}=$ volume $(\mathrm{ml})$ of plankton concentrate in three times.

$\mathrm{V}_{2}=$ volume $(\mathrm{ml})$ of counted cells.

$\mathrm{T}=$ Total number of individual plankter in three replicated counting.

$1000=$ Numerical value of the unit liter (L)

\section{Statistical analysis}

All statistical analyses were performed with the help of a computer software SPSS program.

\section{Results and Discussion}

The results indicated a remarkable seasonal variation of water quality parameters in all the MCRTs. Although the pattern of variation was almost similar, but wide difference obtained in the level of hardness and phosphate determining components and consequent water quality parameters (Table 1). Hence, temperature exerts an immense influence on the maintenance of a healthy aquatic environment and production of food organisms (Brett, 1979) therefore, the mean range of temperature $\left(25.83-26.57^{\circ} \mathrm{C}\right)$ reflected the usual semitropical water including the seasonal variations (Lewis,
2000; Ayoade, 2006) for normal growth of aquatic organisms (Wetzel, 2001; Mazid, 2002). Similar result also reported by Dhawan and Kaur (2002), while, Boyd (1982) suggested that the range of water temperature from $26.06-31.97^{\circ} \mathrm{C}$ is suitable for fish culture. Thus the result showed that the water temperature were within the permissible limit for aquaculture (Table-1). The level of $\mathrm{pH}$ varied from 6.82-8.72, 6.02-8.27, 6.36-8.39, 6.26-8.61 and 6.90-8.89 in MCRT 1-5 respectively. $\mathrm{p}^{\mathrm{H}}$ values varied from 6.26 to 8.89 which coincide with permissible limit for different uses like fish culture, irrigation, domestic and recreational, according to standard value of DoE ( $\mathrm{pH} 6$ to 9). According to Boyd (1982), water $\mathrm{pH}$ values range between 7.0 to 9.0 is the indicative suitable for fish culture. Thus, the obtained $\mathrm{pH}$ values under different treatments were almost healthy for fish culture. Similar results obtained by Dhawan and Kaur (2002); Okbah and Gohary (2002). Kohinoor et al. (2012) reported that the similar range of $\mathrm{pH}$ value even suitable for catfish culture (Table-1). The dissolved oxygen (DO) contents in the experiment ranged between 5.25-9.51, 2.30-8.34, 2.75-9.60, 4.008.73 and $3.34-9.15 \mathrm{mgL}^{-1}$ respectively with the mean values $6.98 \pm 1.05,6.75 \pm 1.53,6.90 \pm 1.64,6.59 \pm 1.19$ and $6.77 \pm 1.60 \mathrm{mgL}^{-1}$. The average DO permit the DO level $6 \mathrm{mgL}^{-1}$ for drinking, 4 to $5 \mathrm{mgL}^{-1}$ for recreation, 4 to 6 $\mathrm{mgL}^{-1}$ for fish and livestock and $5 \mathrm{mgL}^{-1}$ for industrial application (EQS, 1997). The studied values were lower DO in the MCRT-2 and 3 in the later summer to early part of monsoon may be the result of decomposition of plankton and autochthonous organic maters. A similar report was recorded by Okayi (2003). However, the level of DO was within the acceptable ranges (Boyd, 1982) in all the MCRTs throughout the experiments (Table-1).The obtained hardness range in all the MCRTs under different treatments were 41.50-125.00, $32.50-106.00,43.00-124.50,31.50-119.00$ and 41.00$64.50 \mathrm{mgL}^{-1}$ respectively. Boyd (1982) revealed that total hardness values for natural water may vary from greater than 30 up to $150 \mathrm{mgL}^{-1}$.are considered good for fish culture. According to the DoE (Department of Environment), (EQS: Environmental Quality Standard for Bangladesh, 1997) standard, the permissible limit of Hardness of drinking water is 200 to $500 \mathrm{ppm}$. According to Huq and Alam (2005), the hardness standard is $123 \mathrm{ppm}$. Thus the obtained hardness range permit the the treatment were suitable for aquaculture, drinking water, irrigation and domestic purpose (Table1). The recorded range of phosphorus were always within the productive condition (Table-1). Natural waters having phosphorus contents of more than $0.2 \mathrm{mgL}^{-1}$ are likely to be quite productive (Idowu and Ugwumba, 2005). Similar result obtained by Okbah and Gohary (2002). 
Table 1. Water quality parameter (mean \pm SE) of MCRTs under different inorganic fertilizers treatments

\begin{tabular}{|c|c|c|c|c|c|c|c|c|c|c|c|c|c|c|}
\hline MCRTs & Parameters & Mar. & Apr. & May & Jun. & Jul. & Aug. & Sep. & Oct. & Nov. & Dec. & Jan. & Feb. & $\mathrm{M} \pm \mathrm{SD}$ \\
\hline \multirow[t]{5}{*}{ MCRT-1 } & Temp. $\left({ }^{\circ} \mathrm{C}\right)$ & 29.1 & 27.7 & 28.2 & 28.15 & 28.65 & 28.15 & 27.6 & 25.6 & 23.55 & 20.8 & 22.3 & 27.6 & $26.45 \pm 2.75$ \\
\hline & $\mathrm{p}^{\mathrm{H}}$ & 6.96 & 7.36 & 7.21 & 7.03 & 7.14 & 8.72 & 7.34 & 6.86 & 6.82 & 7.36 & 8.61 & 6.98 & $7.37 \pm 0.61$ \\
\hline & $\mathrm{DO}\left(\mathrm{mgl}^{-1}\right)$ & 7.38 & 6.69 & 7.96 & 5.25 & 6.07 & 6.59 & 6.69 & 6.32 & 6.37 & 7.78 & 9.51 & 7.13 & $6.98 \pm 1.05$ \\
\hline & $\operatorname{Hard}\left(\mathrm{mgl}^{-1}\right)$ & 65.5 & 81 & 81.5 & 41.5 & 55 & 62.5 & 58 & 62.5 & 88.5 & 79 & 62.5 & 125 & $71.88 \pm 20.47$ \\
\hline & $\operatorname{Phos}\left(\mathrm{mgl}^{-1}\right)$ & 0.99 & 0.96 & 0.98 & 0.69 & 0.68 & 0.73 & 0.44 & 0.84 & 0.96 & 0.69 & 0.82 & 0.45 & $0.77 \pm 0.18$ \\
\hline \multirow[t]{5}{*}{ MCRT-2 } & Temp $\left({ }^{\circ} \mathrm{C}\right)$ & 29.4 & 26.35 & 29.15 & 27.35 & 29.35 & 28.35 & 28.4 & 27.35 & 24.45 & 23.2 & 18.25 & 26.35 & $26.50 \pm 3.24$ \\
\hline & $\mathrm{p}^{\mathrm{H}}$ & 7.21 & 7.28 & 7.66 & 7.26 & 7.23 & 8.27 & 7.97 & 7.76 & 6.02 & 7.2 & 7.96 & 7.44 & $7.44 \pm 0.55$ \\
\hline & $\mathrm{DO}\left(\mathrm{mgl}^{-1}\right)$ & 8.34 & 6.66 & 7.65 & 2.30 & 5.79 & 6.43 & 7.35 & 6.96 & 6.36 & 8.33 & 7.13 & 7.66 & $6.75 \pm 1.53$ \\
\hline & $\operatorname{Hard}\left(\mathrm{mgl}^{-1}\right)$ & 32.5 & 82.5 & 43 & 61 & 43.5 & 43 & 45 & 79.5 & 82.5 & 106 & 52.5 & 55 & $60.5 \pm 21.25$ \\
\hline & $\operatorname{Phos}\left(\mathrm{mgl}^{-1}\right)$ & 1 & 0.98 & 0.99 & 0.73 & 0.85 & 0.78 & 0.53 & 0.69 & 0.96 & 0.99 & 1 & 0.45 & $0.83 \pm 0.19$ \\
\hline \multirow[t]{5}{*}{ MCRT-3 } & Temp $\left({ }^{\circ} \mathrm{C}\right)$ & 29.55 & 26.25 & 29.5 & 27.25 & 29.25 & 28.45 & 28.45 & 27.25 & 24.35 & 23.3 & 18.2 & 18.15 & $25.83 \pm 4.08$ \\
\hline & $\mathrm{p}^{\mathrm{H}}$ & 7.16 & 6.86 & 7.61 & 7.12 & 7.64 & 8.39 & 7.45 & 7.64 & 6.67 & 7.7 & 6.36 & 6.36 & $7.25 \pm 0.58$ \\
\hline & $\mathrm{DO}\left(\mathrm{mgl}^{-1}\right)$ & 7.20 & 7.00 & 8.75 & 2.75 & 5.61 & 5.79 & 6.84 & 7.40 & 6.67 & 9.60 & 7.57 & 7.57 & $6.90 \pm 1.64$ \\
\hline & $\operatorname{Hard}\left(\mathrm{mgl}^{-1}\right)$ & 43 & 82.5 & 82 & 102.5 & 87.5 & 74.5 & 45.5 & 85 & 119 & 124.5 & 77.5 & 77 & $83.38 \pm 23.39$ \\
\hline & $\operatorname{Phos}\left(\mathrm{mgl}^{-1}\right)$ & 1 & 0.96 & 0.99 & 0.73 & 0.78 & 0.74 & 0.44 & 0.84 & 0.99 & 1 & 0.46 & 0.46 & $0.78 \pm 0.21$ \\
\hline \multirow[t]{5}{*}{ MCRT-4 } & Temp $\left({ }^{\circ} \mathrm{C}\right)$ & 29.25 & 26.45 & 29.55 & 27.05 & 29.55 & 28.35 & 28.15 & 27.45 & 24.35 & 23.1 & 19.4 & 26.15 & $26.57 \pm 3.02$ \\
\hline & $\mathrm{p}^{\mathrm{H}}$ & 7.36 & 6.83 & 7.35 & 7.06 & 7.25 & 8.61 & 7.63 & 7.59 & 6.26 & 7.04 & 7.7 & 7.27 & $7.33 \pm 0.54$ \\
\hline & $\mathrm{DO}\left(\mathrm{mgl}^{-1}\right)$ & 7.05 & 4.00 & 6.15 & 8.73 & 5.45 & 5.95 & 6.55 & 8.07 & 7.25 & 6.38 & 7.37 & 6.16 & $6.59 \pm 1.19$ \\
\hline & $\operatorname{Hard}\left(\mathrm{mgl}^{-1}\right)$ & 50.5 & 82.55 & 64 & 44 & 41 & 42.5 & 31.5 & 32.5 & 119 & 90.5 & 43.5 & 68 & $59.13 \pm 25.57$ \\
\hline & $\operatorname{Phos}\left(\mathrm{mgl}^{-1}\right)$ & 0.99 & 1 & 0.99 & 0.78 & 0.86 & 0.67 & 0.46 & 0.68 & 1 & 0.69 & 0.96 & 1 & $0.84 \pm 0.17$ \\
\hline \multirow[t]{5}{*}{ MCRT-5 } & $\operatorname{Temp}\left({ }^{\circ} \mathrm{C}\right)$ & 29.25 & 26.4 & 29.15 & 27.25 & 29.5 & 28.15 & 28.15 & 27.25 & 24.45 & 23.15 & 19.5 & 26.15 & $26.53 \pm 2.93$ \\
\hline & $\mathrm{p}^{\mathrm{H}}$ & 7.70 & 7.10 & 6.90 & 7.08 & 7.32 & 8.89 & 7.51 & 7.14 & 7.39 & 7.43 & 7.71 & 7.48 & $7.47 \pm 0.49$ \\
\hline & $\mathrm{DO}\left(\mathrm{mgl}^{-1}\right)$ & 6.56 & 4.32 & 6.39 & 8.79 & 3.34 & 6.16 & 7.35 & 6.49 & 7.28 & 9.15 & 8.12 & 7.23 & $6.77 \pm 1.60$ \\
\hline & $\operatorname{Hard}\left(\mathrm{mgl}^{-1}\right)$ & 43.5 & 61 & 62 & 41 & 46.5 & 48.5 & 42.5 & 53.5 & 58.5 & 59 & 51 & 64.5 & $52.63 \pm 7.92$ \\
\hline & $\operatorname{Phos}\left(\mathrm{mgl}^{-1}\right)$ & 1 & 1 & 0.95 & 0.73 & 0.73 & 0.79 & 0.53 & 0.7 & 1 & 0.69 & 1 & 0.95 & $0.84 \pm 0.16$ \\
\hline
\end{tabular}

\section{Plankton population study}

Phytoplankton were five major groups, such as, Cyanophyceae, Chlorophyceae, Bacillariophyceae, Euglenophyceae and Hepateacae were recorded with variation in different MCRTs throughout the studied periods. Among these groups, 27 genera were identified which presented (Table 2). The result showed that the the highest phytoplankton number were in MCRT3.The phytoplankton, while counted in each MCRT throughout the study period showed that the environment as developed due to defined treatment in MCRT-1 produced maximum quantity $57.08 \%$ of Euglenophyceae followed by $21.99 \%$ and $8.03 \%$ of Chlorophyceae and Bacillariophyceae among the all genera of major texa (Table 3). Similarly, in MCRT-2 the percentage composition was dominated by $47.70 \%$ of Euglenophyceae and the next $37.36 \%, 6.32 \%$ and $4.45 \%$ occupied by Chlorophyceae, Cyanophyceae and Hepatecae in the total phytoplankton genera observed (Table 3). The MCRT-3 showed highest percentage composition as $38.96 \%$ of Euglenophyceae, then, $32.78 \%, 23.96 \%$ and $2.41 \%$ of Chlorophyceae, Hepatecae and Cyanophyceae respectively in the total obtained of phytoplankton (Table 3). Within the studied, it was found that the MCRT-4 produced maximum $42.38 \%$ population of Euglenophyceae, $33.84 \%$ Hepatecae, $18.61 \%$ Chlorophyceae (Table 3). At the same time, the controlled MCRT-5, dominated by Euglenophyceae with $42.38 \%$, which followed by Hepatecae and Chlorophyceae by the percentage of $25.0 \%$ to $24.83 \%$ respectively in the total recorded phytoplankton in this study (Table 3 ). 
Table 2. Mean density (indiv. $\mathrm{L}^{-1}$ ) of Phytoplankton and Zooplankton under different major genera as obtained during the study in different MCRTs of Madhupur Tract Soil

\begin{tabular}{|c|c|c|c|c|c|c|c|}
\hline \multicolumn{4}{|c|}{ Phytoplankton } & \multicolumn{4}{|c|}{ Zooplankton } \\
\hline $\begin{array}{l}\text { Major } \\
\text { Taxa }\end{array}$ & Genera & $\begin{array}{l}\text { Total } \\
\text { no. }\end{array}$ & $\begin{array}{l}\text { Mean } \\
\text { Density } \pm \text { SD }\end{array}$ & $\begin{array}{l}\text { Major } \\
\text { Taxa }\end{array}$ & Genera & $\begin{array}{l}\text { Tota } \\
1 \text { no }\end{array}$ & $\begin{array}{l}\text { Mean } \\
\text { Density } \pm \text { SD }\end{array}$ \\
\hline Cyano. & $\begin{array}{l}\text { Aphanocapsa sp } \\
\text { Coelosphaerium sp } \\
\text { Chroococcus sp. } \\
\text { Holopedium sp } \\
\text { Oscillatoria sp. } \\
\text { Skujella sp. }\end{array}$ & $\begin{array}{l}20 \\
21 \\
18 \\
03 \\
97 \\
08\end{array}$ & $\begin{array}{l}4.0 \pm 5.65 \\
4.2 \pm 5.76 \\
3.6 \pm 5.37 \\
0.6 \pm 1.34 \\
19.4 \pm 6.69 \\
1.6 \pm 3.58\end{array}$ & Protozoa & Collosphaera sp. & 275 & $55.0 \pm 17.56$ \\
\hline Chloro. & $\begin{array}{l}\text { Chlorella sp. } \\
\text { Cosmerium sp. } \\
\text { Kirchneriella } s p . \\
\text { Microspora } s p \\
\text { Pithophora } s p \\
\text { Spirogyra sp } \\
\text { Tetraspora sp } \\
\text { Ulothrix sp } \\
\text { Voivox sp }\end{array}$ & $\begin{array}{l}890 \\
58 \\
03 \\
07 \\
22 \\
05 \\
05 \\
02 \\
393\end{array}$ & $\begin{array}{l}178.0 \pm 59.66 \\
11.6 \pm 14.17 \\
0.6 \pm 1.34 \\
1.4 \pm 3.13 \\
4.4 \pm 9.84 \\
1.0 \pm 2.24 \\
1.0 \pm 2.24 \\
0.4 \pm 0.89 \\
78.6 \pm 133.71\end{array}$ & Rotifera & Asplanchna sp. & 584 & $116.80 \pm 88.37$ \\
\hline Eug. & $\begin{array}{l}\text { Euglena sp. } \\
\text { Phaecus sp. }\end{array}$ & $\begin{array}{l}2159 \\
83\end{array}$ & $\begin{array}{l}431.8 \pm 197.5 \\
16.6 \pm 3.91\end{array}$ & Cladocera & $\begin{array}{l}\text { Daphnia sp. } \\
\text { Diaphanosoma } \\
\text { sp. } \\
\text { Bosmina sp. }\end{array}$ & $\begin{array}{l}61 \\
44 \\
87\end{array}$ & $\begin{array}{l}12.20 \pm 16.89 \\
8.80 \pm 12.13 \\
17.40 \pm 16.85\end{array}$ \\
\hline Hep. & Riccia sp. & 1165 & $233.0 \pm 215.9$ & Copepoda & $\begin{array}{l}\text { Cyclops sp. } \\
\text { Eucalanus sp. }\end{array}$ & $\begin{array}{l}129 \\
51 \\
\end{array}$ & $\begin{array}{l}25.80 \pm 17.05 \\
10.20 \pm 22.81\end{array}$ \\
\hline & & & & Ostracoda & Cypris sp. & 436 & $87.20 \pm 54.90$ \\
\hline
\end{tabular}

These were Protozoa, Rotifera, Cladocera, Copepoda and Ostracoda. Again, among them only Cladocera and Copepoda were represented by the three and two genera respectively, while, the rest with one genus of each. However, the maximum mean density $116.80 \pm 88.37$ indivL $L^{-1}$ shown by the Rotifera, of all Zooplankton observed. The second and third dominant group was Ostracoda and Protozoa with 87.20 \pm 54.90 and $55.0 \pm 17.56$ indivL $^{-1}$ of the total Zooplankton studied (Table 2). From this study it was found that the number of Zooplankton was highest in MCRT-3 (Table 3). The study recorded 8 genera in Madhupur tract soils, under 5 major taxa throughout studied period. Hutchinson (1967) concluded that the main groups composing zooplankton communities are the protozoans, rotifers and crustaceans, particularly copepods and cladocerans, although freshwater zooplankton especially in tropical regions may contain a diverse set of taxonomical categories (Dummont et al., 1994; Wetzel, 2001). Jhingran (1985) and several other scientists reported about the diurnal vertical migration of certain Zooplankters, but considering the depth of MCRTs, such a probability can be omitted here. MBO (2007); Davies and Otene (2009) concluded that the abundance and distribution of planktonic organisms might be adduced to many factors such as, DO, transparency, depth, salinity, $\mathrm{pH}$, temperature and nutrients. FAO (2006) opined that the distribution and composition vary from place to place and year to year due to the dynamic nature of the aquatic systems. 
Table 3. Density (indiv. $\mathrm{L}^{-1}$ ) of Phytoplankton and Zooplankton with percentages under different major group as obtained during the study in different MCRTs of Madhupur Tract Soil

\begin{tabular}{|c|c|c|c|c|c|c|c|}
\hline \multirow[t]{6}{*}{ MCRT-1 } & Phytoplankton & Cyanophyceae & Chlorophyceae & Bacillariophyceae & Euglenophyceae & Hepaticae & Total \\
\hline & Indiv./L & 29 & 126 & 46 & 327 & 45 & 573 \\
\hline & $\%$ & 5.06 & 21.99 & 8.03 & 57.08 & 7.85 & 11.14 \\
\hline & Zooplankton & Protozoa & Rotifera & Cladocera & Copepoda & Ostracoda & Total \\
\hline & Indiv./L & 42 & 117 & 58 & 45 & 158 & 420 \\
\hline & $\%$ & 10 & 27.85 & 13.81 & 10.71 & 37 & 25.19 \\
\hline \multirow[t]{6}{*}{ MCRT-2 } & Phytoplankton & Cyanophyceae & Chlorophyceae & Bacillariophyceae & Euglenophyceae & Hepaticae & Total \\
\hline & Indiv./L & 44 & 260 & 29 & 332 & 31 & 696 \\
\hline & $\%$ & 6.32 & 37.36 & 4.17 & 47.7 & 4.45 & 13.53 \\
\hline & Zooplankton & Protozoa & Rotifera & Cladocera & Copepoda & Ostracoda & Total \\
\hline & Indiv./L & 52 & 55 & 58 & 35 & 58 & 258 \\
\hline & $\%$ & 20.15 & 21.31 & 22.48 & 13.57 & 22.48 & 15.48 \\
\hline \multirow[t]{6}{*}{ MCRT-3 } & Phytoplankton & Cyanophyceae & Chlorophyceae & Bacillariophyceae & Euglenophyceae & Hepaticae & Total \\
\hline & Indiv./L & 41 & 557 & 32 & 662 & 407 & 1699 \\
\hline & $\%$ & 2.41 & 32.78 & 1.88 & 38.96 & 23.96 & 33.04 \\
\hline & Zooplankton & Protozoa & Rotifera & Cladocera & Copepoda & Ostracoda & Total \\
\hline & Indiv./L & 71 & 250 & 23 & 29 & 132 & 505 \\
\hline & $\%$ & 14.05 & 49.5 & 4.55 & 5.74 & 26.13 & 30.29 \\
\hline \multirow[t]{6}{*}{ MCRT-4 } & Phytoplankton & Cyanophyceae & Chlorophyceae & Bacillariophyceae & Euglenophyceae & Hepaticae & Total \\
\hline & Indiv./L & 29 & 292 & 52 & 665 & 531 & 1569 \\
\hline & $\%$ & 1.85 & 18.61 & 3.31 & 42.38 & 33.84 & 30.51 \\
\hline & Zooplankton & Protozoa & Rotifera & Cladocera & Copepoda & Ostracoda & Total \\
\hline & Indiv./L & 75 & 131 & 27 & 52 & 59 & 344 \\
\hline & $\%$ & 21.8 & 38.08 & 7.85 & 15.11 & 17.15 & 20.63 \\
\hline \multirow[t]{6}{*}{ MCRT-5 } & Phytoplankton & Cyanophyceae & Chlorophyceae & Bacillariophyceae & Euglenophyceae & Hepaticae & Total \\
\hline & Indiv./L & 24 & 150 & 23 & 256 & 151 & 604 \\
\hline & $\%$ & 3.97 & 24.83 & 3.81 & 42.38 & 25 & 11.74 \\
\hline & Zooplankton & Protozoa & Rotifera & Cladocera & Copepoda & Ostracoda & Total \\
\hline & Indiv./L & 35 & 31 & 26 & 19 & 29 & 140 \\
\hline & $\%$ & 25 & 22.14 & 18.57 & 13.57 & 20.71 & 8.39 \\
\hline
\end{tabular}

\section{Conclusions}

From this study it can be concluded that successive improvement on the productive conditions within all the MCRTs were found. Among doses, the dose which treated in the MCRT-3 given best result. The characteristics of different species of plankton can sometimes help scientists to distinguish one water mass from another.

\section{References}

Ahmed, K. K..; Haque, M. K. I.; Halder, G. C. and Saha, S. B. 1997. Ecological studies on the planktonic organisms of Kaptai Lake. Bangladesh J. Agric., 22: 63-67.

Ali, M. Y. 1997. Fish, Water and people. Reflections on inland open water fisheries resources of Bangladesh. The University Press Limited. Red Crescent Building, 114 Motijheel, Dhaka-1000, 1-15p.

Alikunhi, K. H. et al., 1955. Aquatic insects and other predators cause considerable damage to the carp fry in the nursery ponds. Ind. J. Fish., 2: 297-323.

AOAC. 1989. Official Methods of Analysis of the Association of Official Analytical Chemistry. $4^{\text {th }}$ Ed., AOAC, Washington DC.
APHA. 1998. Standard methods for the examination of water and wastewater $\left(20^{\text {th }}\right.$ edn.) American Public Health Association, Washington.

Ayoade, A. A.; Fagade, S. O. and Adebisi, A. A. 2006. Dynamics of limnological features of two manmade lakes in relation to fish production. Afr. J. Biotechnol., 5(10): 1013-1021.

Bernacsek, G. M. S.; Nandi, S. and Paul, N. C. 1992. Draft of the systematic study: Fishes in the North East Region of Bangladesh. North East Region water management project (FAP-6).

Bhakta, N. J.; Bandyopadhyay, K. P. and Jana, B. B. 2006. Effect of different doses of mixed fertilizer on some biogeochemical cycling bacterial population in carp culture pond. Turkish J. of Fisheries and Aquatic Sciences, 6: 165-171.

Boyd, C. E. 1982. Water Quality Management for Pond Fish Culture. Elsevier, The Netherlands. 318 p.

Brett, J. R. 1979. Environmental factors and growth. In: Summer Institute of Farming System Integrating agriculture and livestock. $8 \mathrm{p}$.

Colman, J. A. and Edwards, P. 1987. Feeding pathways and environmental constraints in waste feed 
aquaculture: Balance and optimization. Manila, Philippines, p 240-281.

Davies, O. A. and Otene, B. B. 2009. Zooplankton community of Minichinda Stream, Port Harcourt, Rivers State, Nigeria. European Journal of Scientific Research, 26(4): 490-498.

De Silva, S. S. and Hasan, M. R. 2007. Study and analysis of feeds and fertilizers for sustainable aquaculture development. FAO fisheries technical paper, No. 497, Rome, FAO. pp. 19-47.

Dhawan, A. and Kaur, S. 2002. Pig Dung as Pond Manure: Effect on Water Quality, Pond Productivity and Crowth of Carps in Polyculture System. ICLARM, 25(1): 11- 14.

DoE (Department of Environment). 2001.The general over view of pollution status of river of Bangladesh. Government of the People's Republic of Bangladesh, Ministry of Environment and Forest, Department of Environment, Dhaka, Bangladesh.

Dummont, H. J.; Rocha, O. and Tundisi, J. G. 1994. The impact of predation in structuring zooplankton communities with emphasis on some lakes in Brazil. Proceedings of Anales del Seminario International del Agua. Mazatlan, Mexico, p.11-43.

EQS (Environmental Quality Standard). 1997. Government of the People's Republic of Bangladesh. Ministry of Environment and Forest, Department of Environment, Gazette, registered nr. DA-1, Dhaka, Bangladesh.

FAO. 2006. Interrelationship between fish and plankton in inland water. Retrieved Sept. 29. Rome.

Haroon, A. K. Y.; Halder, G. C.; Rahman, S. L.; Razzaque, M. A.; Alam, M. and Nurul, S. M. A. 2002. Sylhet-Mymenshing basin fish stock assessment, Bangladesh Fisheries Research Institute, Riverine Station, Chandpur, Bangladesh, $\mathrm{p}$ 81.

Hora, S. L. and Pillay, T. V. R. 1962. Handbook of fish culture in the Indo-Pacific region. FAO Fish. Biol. Tech. Pap., 14: 204.

Huet, M. 1975. Textbook of Fish Culture, Breeding and Cultivation of Fish. Fishing News (Books) Ltd. Page Bros (Norwich) Ltd, Norwich.

Huq, S. M. I. and Alam, M. D. 2005. A Handbook on Analysis of Soil, Plant and Water. BACER-DU, University of Dhaka, Bangladesh.

Hutchinson, G. E. 1967. A Treatise on Limnology. Introduction to lake biology and the limnoplankton. John Wiley \& Sons, Inc., New York, 2: 1115.
Jha, P.; Barat, S. and Nayak, C. R. 2008. Fish production, water quality and bacteriological parameters of Koi carp ponds under live-food and manure based management regimes. Zoological research, 2: 165-173.

Jhingran, V. G. 1985. Fish and Fisheries of India (Revised and Enlarged Second Edition): Hindustan Publishing Corporation (India) New Delhi 110020; $666 \mathrm{p}$.

Joadder, A. R. 2009. An Ecological Study on the Beel Joshi (Rajshahi District), Northern Bangladesh. Journal of Fisheries International, 4(2): 23-29.

Kohinoor, A. H. M.; Khan, M. M.; Yeasmine, S.; Mandol, P. and Islam, M. S. 2012. Effect of stocking density on growth and production performance of indigenous stinging catfish, Heteropneustes fosssilis (Bloch). Int. J. Agril. Res. Innov. \& Tech., 2(2): 9-14.

Le Mare, D. W. 1948. Weeding in fish farming. Nature, Lond., 162: 704.

Lewis, W. M. 2000. Basis for the protection and management of tropical lakes. Lakes Reserv. Res. Manage., 5: 35-48.

Lickacz, J. and Penny, D. 2001. Soil Organic Matter. AGRI-FACTS, Government of Alberta Plant Industry Division.

Mazid, M. A. 2002. Development of Fisheries in Bangladesh (Plans and Strategies for Income Generation and Poverty Alleviation), $176 \mathrm{p}$.

MBO. 2007. Zooplankton. www.marine. Bio.com/Ocean/Zooplankton.

Okayi, R. G. 2003. Effect of effluent discharge on water quality, distribution and abundance of plankton and fish species of River Benue. University of Ibadan. Oklahoma Cooperative Extension Fact Sheets, Oklahoma,.

Okbah, M. A. and El-Gohary, S. El. 2002. Physical and Chemical characteristics of lake Edku water, Egypt. Mediterranean Marine Science, 3(2): 27-39.

Pillay, T. V. R. 1993. Aquaculture, principle and practices. Fishing News Books. University Press, Cambridge.

Schaperclaus, W. 1933. Lehrbuch der TeichwirtschaJt. P. Parey, 1. Auflage, Berlinund Hamburg.

Wetzel, R. G. 2001. Limnology Lake and River Ecosystems. Academic Press. A Harcourt Science and Technology Company, USA.

Zehmen, V. 1917. Teichdungung(pond manuring). Mitt dents. Landw, Ges., 32: 306-09. 